\title{
X-RAY DIFFRACTION LINE PROFILE ANALYSIS OF STRONGLY TEXTURED THIN FILMS OF Zn0
}

$\mathrm{ZnO}$ thin films have been deposited on $\mathrm{SiO}_{2}$-Si and $\mathrm{Al}_{-} \mathrm{SiO}_{2}$-Si substrates by reactive sputtering. X-ray diffractometry was used to determine microstructural disorder parameters in $\mathrm{ZnO}$ thin films with strong preferred c-axis orientation. The influence of $\mathrm{Al}_{\text {and }} \mathrm{Al}_{2} \mathrm{O}_{3}$ buffer layer on preferred c-axis orientation and microstrain of crystallites was also studied. The microstrains and domain size showed only a small dependence on the preference of a buffer layer, but they depend on the thickness of $\mathrm{ZnO}$ thin film. The stress gradient along the c-axis was observed in all of studied samples.

\section{Introduction}

Thin films of metallic conductors, semiconductors and insulators are the basic materials for modern electronic devices. For optimal device performance, these films should possess specific mechanical, electrical, magnetic or optical properties which are strongly influenced by the microstructural qualities of the films such as crystalline or amorphous state, crystallographic orientation, crystallite size, strain and stresses. Therefore, microstructural characterization of thin films is very important for the design and improvement of electronic devices [1].

Due to their small dimensions perpendicular to the surface, the microstructure of thin films cannot be easily characterized by methods developed for the bulk materials. Therefore, various methods of surface physics are frequently applied to thin films. Among the analytical methods especially suitable for thin films, X-ray diffraction plays an important role since it is nondestructive, noncontact and highly quantitative.

However, due to the thinness of the film the diffracting volume is normally very small resulting in weak diffracted intensities. On the other hand, due to preferred orientation of crystallites in a certain direction, some diffraction lines can reach very strong intensities so that in such case there is no problem to apply line profile analysis to obtain the basic structural characteristics of thin films.

In line profile analysis mainly broadening and shape of diffraction line are investigated. Broadening of X-ray diffraction line profile is mainly caused by nonideal optics of the instrument, wavelength dispersion and structural imperfections of the specimen. The structural line broadening is often subdivided into size broadening and strain broadening. Size broadening is caused by the finite size of domains diffracting essentially incoherently with respect to one another. On the other hand, strain broadening is caused by varying displacements of the atoms with respect to their reference-lattice positions [2].
Line broadening is frequently characterized by means of one or two breadth measures (FWHM - full width at half maximum and $\beta=$ Area $/ l_{0}$ - integral breadth) and separation of size and strain contributions have been performed on this basis [3, 4]. More detailed analysis is possible by taking into account the complete shape of a line profile by expressing it in terms of Fourier coefficients. Both breadth and Fourier methods gain in reliability when more than one order of reflection is used for a given set of lattice planes [5].

\section{Experimental procedure}

In our work, ceramic and metallic thin films deposited on single-crystalline silicon wafers by means of diode sputtering were investigated. In special cases $\mathrm{Al}, \mathrm{SiO}_{2}$ and $\mathrm{Al}_{2} \mathrm{O}_{3}$ buffer layers were also applied. A planar r.f. sputtering system Perkin Elmer 2400/8L was used. The sputtering chamber was always pumped down to $2 \cdot 10^{-5} \mathrm{~Pa}$ before admission of working gas $\left(\mathrm{Ar}\right.$ or $\mathrm{Ar} / \mathrm{O}_{2}$ gas mixture $99,999 \%$ in purity). Throughout the sputtering of $\mathrm{Al}, \mathrm{ZnO}$ and $\mathrm{Al}_{2} \mathrm{O}_{3}$ targets (each $203 \mathrm{~mm}$ in diameter and $99.95 \%$ in purity) a gas pressure of $1.3 \mathrm{~Pa}$ was kept constant [6,7]. The temperature of substrate was mostly kept at room temperature. In special cases the temperature of substrate was kept at $300{ }^{\circ} \mathrm{C}$ or at $600{ }^{\circ} \mathrm{C}$. The effects of different r.f. powers, different substrates and different film thicknesses were investigated. Furthermore, different ratios of $\mathrm{Ar} / \mathrm{O}_{2}$ gas mixture in case of $\mathrm{ZnO}$ films as well as the cyclic sputtering and ion etching of films were applied [8,9]. The general characterisation of sputtered films is listed in Table I.

X-ray diffraction line profile analysis was used to determine microstructural properties of investigated films. First, preliminary diffraction patterns were recorded on the film. After that, the X-ray diffraction data were collected by using an automatic X-ray powder diffractometer URD-6 with a Bragg-Brentano goniometer. A copper X-ray tube $(\lambda=0,154178 \mathrm{~nm})$ was used. Ceramic $\mathrm{Al}_{2} \mathrm{O}_{3}$ from NIST was used as an instrumental standard. The intensities of

\footnotetext{
* ${ }^{1}$ P. Sutta, ${ }^{2} Q$. Jackuliak

${ }^{1}$ Department of Physics, Faculty of Logistics, Military Academy 03111 Liptovský Mikulaš

${ }^{2}$ Department of Technical Physics, Faculty of Electrical Engineering, University of Žilina, 01026 Žilina
} 
Characterisation of investigated thin films

Table 1

\begin{tabular}{|c|c|c|c|c|c|}
\hline Sample (thin film) & Special condition & $\begin{array}{c}\text { Substrate } \\
\text { configuration }\end{array}$ & R. F. Power $[\mathrm{W}]$ & Thickness [nm] & $\begin{array}{c}\text { Substrate } \\
\text { temperature }\left[{ }^{\circ} \mathrm{C}\right]\end{array}$ \\
\hline $\mathrm{ZnO} 1$ & $\mathrm{Ar}+\mathrm{O}_{2}(25 / 75)$ & $\mathrm{Al} / \mathrm{SiO}_{2} / \mathrm{Si}$ & 500 & 1000 & room \\
\hline $\mathrm{ZnO} 2$ & $\mathrm{Ar}+\mathrm{O}_{2}(25 / 75)$ & $\mathrm{SiO}_{2} / \mathrm{Si}$ & 500 & 1000 & room \\
\hline $\mathrm{ZnO} 3$ & $\mathrm{Ar}+\mathrm{O}_{2}(60 / 40)$ & $\mathrm{Al} / \mathrm{SiO}_{2} / \mathrm{Si}$ & 500 & 1000 & room \\
\hline $\mathrm{ZnO} 4$ & $\mathrm{Ar}+\mathrm{O}_{2}(60 / 40)$ & $\mathrm{SiO}_{2} / \mathrm{Si}$ & 500 & 1000 & room \\
\hline $\mathrm{ZnO} 5$ & $\mathrm{Ar}+\mathrm{O}_{2}(25 / 75)$ & $\mathrm{Al}_{2} / \mathrm{SiO}_{2} / \mathrm{Si}$ & 500 & 2500 & 300 \\
\hline $\mathrm{ZnO} 6$ & $\mathrm{Ar}+\mathrm{O}_{2}(25 / 75)$ & $\mathrm{Al}_{2} \mathrm{O}_{3} / \mathrm{Al} / \mathrm{SiO}_{2} / \mathrm{Si}$ & 500 & 2500 & 300 \\
\hline $\mathrm{ZnxOy} 1$ & Multilayers & $\mathrm{Al}_{2} \mathrm{O}_{3} / \mathrm{SiO}_{2} / \mathrm{Si}$ & 500 & 250 & room \\
\hline $\mathrm{ZnxOy} 2$ & Multilayers & $\mathrm{Al}_{2} \mathrm{O}_{3} / \mathrm{SiO}_{2} / \mathrm{Si}$ & 500 & 250 & 300 \\
\hline ZnxOy 3 & Multilayers & $\mathrm{Al}_{2} \mathrm{O}_{3} / \mathrm{SiO}_{2} / \mathrm{Si}$ & 500 & 250 & 600 \\
\hline
\end{tabular}

diffraction lines were collected with a constant step of 0.02 deg of 2-theta and with a constant counting time of 20 seconds at each step. In order to appreciate degree of preferred orientation, the omegascans of the most intensive diffraction lines for each material were also recorded.

From several available methods appropriate for the line profile analysis a single-line method based on a Voigt function [3] which is more versatile and powerful from the practical point of view was used to determine size-strain parameters (microstrains and crystallite sizes) of investigated thin films [4]. Because no monochromator was used, the $\mathrm{K}_{\alpha 2}$ line had to be removed by a graphic method $[10,11]$.

\section{Results and discussion}

Because Zinc Oxide has a hexagonal close-packed wurtzite structure, polycrystalline thin films prepared by different techniques have usually preferential orientation of their grains in the [001]

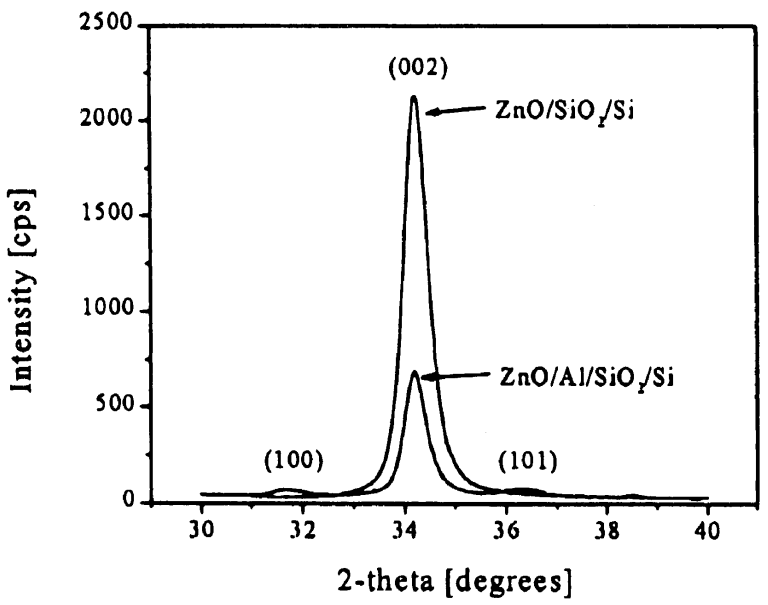

Fig. 1. Influence of aluminium buffer layer on preferred orientation of $\mathrm{ZnO}$ film (Samples $\mathrm{ZnO} 1$ and $\mathrm{ZnO} 2$ ). direction perpendicular to the substrate, strongly depending on the deposition conditions in the deposition unit.

Diffraction patterns preliminary recorded on the film indicated that all investigated films were polycrystalline. Almost in all cases, a very strong preferred orientation of crystallites perpendicular to the substrate, depending on the material and on the special conditions in the course of deposition, was observed. In case of zinc oxide films the preferred orientation is mainly in the [001] direction.

In case of continual sputtering there is a [001] preferred orientation of crystallites perpendicular to the substrate. (See X-ray diffraction patterns presented in fig. 1, 2 and 3).

The aluminium conductive layer resulted in a decrease of preferred orientation of $\mathrm{ZnO}$ crystallites (Fig. 1 and 2) as well as decrease of lattice imperfections, which can be observed in decreasing of microdeformations. Furthermore, in all cases of $\mathrm{ZnO}$ films whose thickness is $1 \mu \mathrm{m}$ or less a considerable shift of (002) dif-

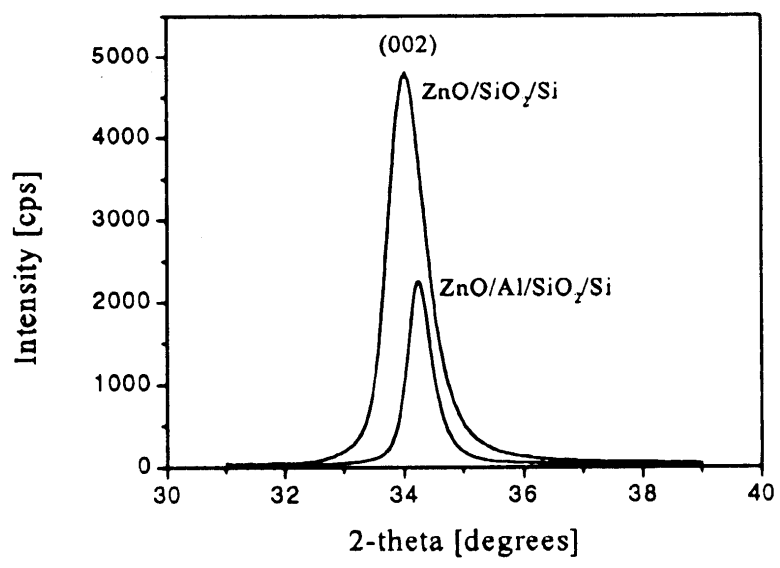

Fig. 2. Influence of $\mathrm{O}_{2}$ content in gas mixture on preferred orientation on $\mathrm{ZnO}$ thin film (Samples $\mathrm{ZnO} 3$ and $\mathrm{ZnO} 4$ ). 
fraction lines towards the lower diffraction angles was observed. When the thickness of $\mathrm{ZnO}$ film was $2,5 \mu \mathrm{m}$ a considerable shift of (002) diffraction lines towards the higher diffraction angles was observed (See Table 2). Regular position of (002) ZnO line according to JCPDS standard is $34.44 \mathrm{deg}$. This line displacement is accompanied with the lattice strains which are present in the $\mathrm{ZnO}$ films due to lattice mismatch between the layer and substrate and due to the ion bombardment of films.

The increase of thickness from $1 \mu \mathrm{m}$ to $2.5 \mu \mathrm{m}$ resulted in considerable increase of crystallite size and decrease of the microstrains. Insertion of an $\mathrm{Al}_{2} \mathrm{O}_{3}$ layer between the $\mathrm{Al}$ and $\mathrm{ZnO}$ layers resulted in further increase of the crystallite size and decrease of the microstrains (Table 3).

It is apparent from Figure 3 that the use of $0.13 \mathrm{~mm}$ receiving slit on a diffractometer shows better asymmetry of the (002) line of $\mathrm{ZnO}$ thin films. The reason for this asymmetry is the stress gradient along the c-axis.

Influence of $\mathrm{Al}_{2} \mathrm{O}_{3}$ buffer layer on omega-scan is showed in Figure 4. The $\mathrm{Al}_{2} \mathrm{O}_{3}$ buffer layer resulted in an increase in width of the omega-scan trace.

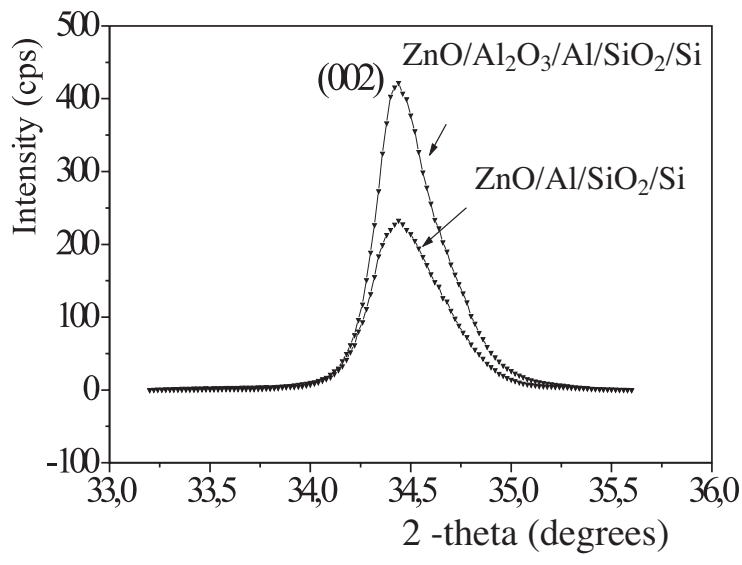

Fig. 3. Influence of $\mathrm{Al}_{2} \mathrm{O}_{3}$ buffer layer and thickness of $\mathrm{ZnO}$ thin film on preferred orientation of $\mathrm{ZnO}$ film (Samples $\mathrm{ZnO} 5$ and $\mathrm{ZnO} 6$ ).

The texture evolution depending on the substrate temperature during the deposition can be demonstrated on $\mathrm{Zn}_{\mathrm{x}} \mathrm{O}_{\mathrm{y}} / \mathrm{Al}_{2} \mathrm{O}_{3}$ multilayered structures prepared as sensitive layers for UV radiation. When substrate temperature during the deposition was kept below $300{ }^{\circ} \mathrm{C}$, a part of amorphous phase was also observed. Much better

Data of investigated thin films obtained from X-ray diffraction

Table 2

\begin{tabular}{|c|c|c|c|c|c|}
\hline Sample (thin film) & Investigated line & Line position & $\begin{array}{c}\text { Intensity } \\
\text { of } \mathrm{K}_{\alpha 1}[\mathrm{cps}]\end{array}$ & FWHM [deg] & $\begin{array}{c}\text { Integrated intensity } \\
{[\mathrm{deg} / \mathrm{s}]}\end{array}$ \\
\hline $\mathrm{ZnO} 1$ & 002 & 34.184 & 436 & 0.4825 & 282.8 \\
\hline $\mathrm{ZnO} 2$ & 002 & 34.205 & 1437 & 0.5568 & 1052 \\
\hline $\mathrm{ZnO} 3$ & 002 & 34.216 & 1664 & 0.4591 & 1016 \\
\hline $\mathrm{ZnO} 4$ & 002 & 34.027 & 2445 & 0.7335 & 2218 \\
\hline $\mathrm{ZnO} 5$ & 002 & 34.480 & 1210 & 0.340 & 458.6 \\
\hline $\mathrm{ZnO} 6$ & 002 & 34.480 & 2170 & 0.275 & 720.4 \\
\hline $\mathrm{Zn}_{\mathrm{x}} \mathrm{O}_{\mathrm{y}}$ & 002 & 34.265 & 5.9 & 0.4453 & 3,3 \\
\hline $\mathrm{Zn}_{\mathrm{x}} \mathrm{O}_{\mathrm{y}}$ & 002 & 34.379 & 32.47 & 0.5799 & 24.4 \\
\hline $\mathrm{Zn}_{\mathrm{x}} \mathrm{O}_{\mathrm{y}} 3$ & 002 & 34.372 & 724.4 & 0.4254 & 365.7 \\
\hline
\end{tabular}

Size-strain data of investigated thin films

Table 3

\begin{tabular}{|c|c|c|c|c|c|}
\hline Sample (thin film) & Investigated line & $\begin{array}{c}\text { Integral breadth } \\
{[\mathrm{deg}] \beta}\end{array}$ & $\begin{array}{c}\text { Shape factor } \\
\Phi=\mathrm{FWHM} / \beta\end{array}$ & $\begin{array}{c}\text { Microstrains } \\
\langle\epsilon\rangle \cdot 10^{3}\end{array}$ & $\begin{array}{c}\text { Crystallite size } \\
\mathrm{D}[\mathrm{nm}]\end{array}$ \\
\hline ZnO 1 & 002 & 0.6493 & 0.7452 & 4.5 & 26 \\
\hline ZnO 2 & 002 & 0.7171 & 0.7764 & 5.9 & 28 \\
\hline ZnO 3 & 002 & 0.6104 & 0.7522 & 4.5 & 29 \\
\hline ZnO 4 & 002 & 0.9070 & 0.8087 & 8.6 & 170 \\
\hline ZnO 5 & 002 & 0.3791 & 0.8790 & 2.6 & 400 \\
\hline ZnO 6 & 002 & 0.3555 & 0.8208 & 1.6 & 27 \\
\hline ZnxOy 2 & 002 & 0.7462 & 0.7772 & 6.2 & 97 \\
\hline ZnxOy 3 & 002 & 0.5480 & 0.8427 & 5.3 & 27 \\
\hline
\end{tabular}




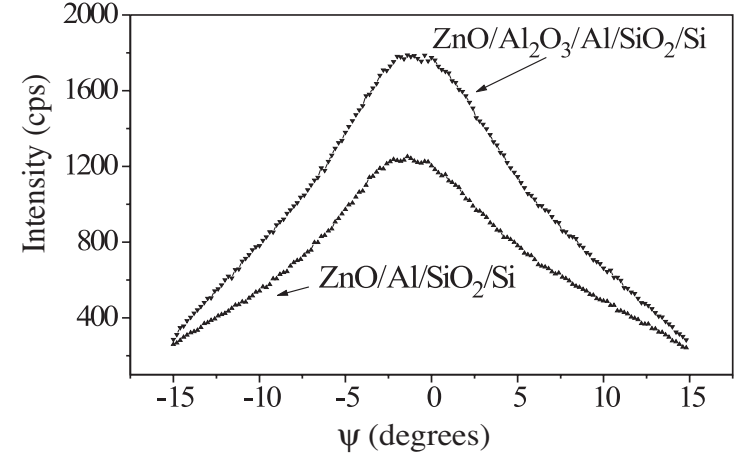

Fig. 4. Influence of $\mathrm{Al}_{2} \mathrm{O}_{3}$ buffer layer on the orientation distribution function of (002) planes $\mathrm{ZnO}$ thin film (Samples $\mathrm{ZnO} 5$ and $\mathrm{ZnO} 6$ ).

preferred orientation was observed when substrate temperature was kept on $600{ }^{\circ} \mathrm{C}$ (See Figure 5 and Table 2).

\section{Conclusions}

Our experiments indicated that the X-ray diffraction line profile analysis carried out on common X-ray diffractometer can be successfully used when investigating the microstructural properties of strongly textured thin films. The analysis is successful also in case when the film thickness is less than one micrometer. More attention has to be paid to the narrow lines because in case of their approximation by a non-appropriate profile the results can be overor underestimated.

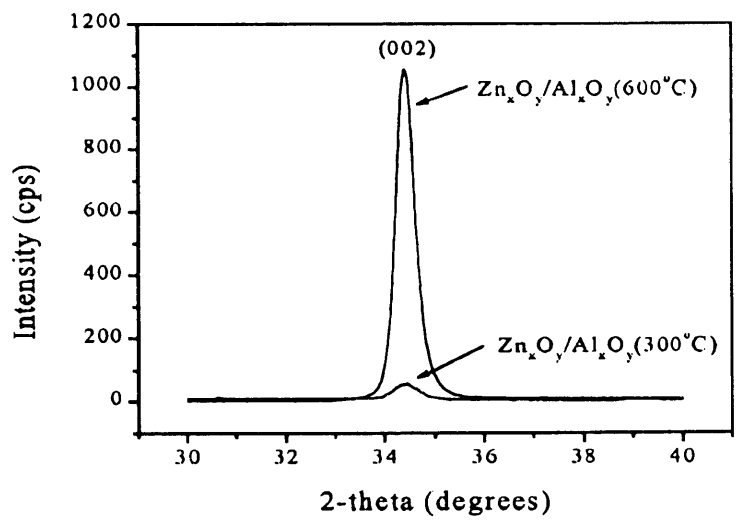

Fig. 5. Influence of substrate temperature on preferred orientation of $\mathrm{Zn}_{x} \mathrm{O}_{y} / \mathrm{Al}_{2} \mathrm{O}_{3}$ multilayered structure (Sample $\mathrm{Zn}_{x} \mathrm{O}_{y} 2$ and $\mathrm{Zn}_{x} \mathrm{O}_{y} \quad 3$ ).

The obtained data about the influence of technology of preparation of thin films of $\mathrm{ZnO}$ as well as buffer layers on the structure of thin films of $\mathrm{ZnO}$ as well as other physical aspects were used to the improvement of preparation of the sensors of stress based on thin films of $\mathrm{ZnO}[7,8]$.

\section{Acknowledgement}

The authors - would like to thank Prof. V. Tvarožek and Dr. 1. Novotny from Slovak University of Technology Bratislava for the preparing of samples and Prof. J.Fiala from ŠKODA Research Ltd. Plzeň, for the recording of preliminary diffraction patterns on the film and for valuable discussions during the preparation of the paper.

\section{References}

[1] SEGMULLER, A., NOYAN, I. C., SPERIOSU, V. S.: X-ray Diffraction Studies of Thin Films and Multilayer Structures, Prog. Crystal Growth and Charact. 18. (1989) pp. 21 - 66

[2] VAN BEI-KUM, J. G. M., VERMEULEN, A. C., DELHEZ, R., DE KEIJSER, TH. H., MITTEMEIJER, E. J.: Applicabilities of the WarrenAverbach Analysis and an Alternative Analysis for Separation of Size and Strain Broadening, J. Appl. Cryst.1-7, (1994) pp. 345 - 357

[3] LANGFORD, J. I. : A Rapid Method for Analysing the Breadths of Diffraction and Spectral Lines using the Voigt Function, J. Appl. Cryst. II, (1978) pp. 10 - 14

[4] DELHEZ, R., DE KEIJSER, TH. H., MITTEMEIJER, E. J.: Determination of Crystallite Size and Lattice Distortions through X-ray Diffraction Line Profile Analysis, Fresenius Z. Anal. Chem. 312, (1982) pp. 1 - 16

[5] BALZAR, D., LEDBETTER, H.: Voigt-Function Modeling in Fourier Analysis of Size- and Strain-Broadened X-ray Diffraction Peaks, J. Appl. Cryst. 26, (1993) pp. 97 - 103

[6] TVAROZEK, V. et al.: Sensors and Actuators B, 18-19,(1994) pp. 597 - 602

[7] TVAROZEK, V.: Microsystem Technology in Biosensors. D.P. Nikolelis et al (eds.), Biosensors for Direct Monitoring of Environmental Pollutants in Field, 351 - 371, Kluwer Academic Publishers. Printed in the Netherlands. (1998)

[8] NOVOTNY, L., SUTTA, P., MIKA, F., TVAROZEK, V.: Piezoelectric ZnO Thin Films Prepared by Cyclic Sputtering and Etching Technology, In: Proc. of the 20th International Conference on Microelectronics MIEL 95, Vol. I, held in Nis, Serbia, 12-14 September 1995 pp. $65-68$

[9] SUTTA, P., et al.: X-ray Diffraction Analysis and Optical Properties of ZnO Thin Films Prepared by Cyclic Sputtering and Etching Technique, In: Proc. of the international conference ASDAM'96, held in October 22 - 26, 1996, Smolenice, Slovakia

[10] JACKULIAK, Q., SUTTA, P.: Refinement of Method for Calculation of $K_{\alpha 1}$ and $K_{\alpha 2}$ Components of Diffraction Line, In: Materials Structure in Chemistry, Biology, Physics and Technology. Vol. 3, (1996) No. 3, pp. $267-269$

[11] BOROVSKIJ, I. B.: Fizičeskije osnovy rentgenospektral'nych issledovanij, lzdatel'stvo Moskovskogo universiteta, Moskva 1956 